\title{
Teacher Talk and Teacher Discursive Moves: A Systematic Review from Vygotskian Perspective
}

Yılmaz SOYSAL, İstanbul Aydın University, yilmazsoysal@aydin.edu.tr, ORCID: 0000-0003-1352-8421

\begin{abstract}
In this study, qualitatively-oriented content of research studies pertaining in-class usage of teacher discursive moves (TDMs) was examined in a fine-grained sense in the context of teaching science. For this purpose, within the scope of the present systematic review, 31 research studies available in the related literature were explored by means of various theoretical perspectives (e.g., communicative approaches, Vygotskian perspective, learning demand, etc.). TDMs practised on various studies had both dialogic and monologic tendency. In addition, the thematic representations extracted at the end of coding and categorisation processes showed that the TDMs incorporate a hierarchy regarding supporting teaching. In addition, most studies did not address the TDMs that could help learners to internalise science phenomena. Recommendations were offered to teacher educators and teachers in the junction of professional pedagogical development and the TDMs.
\end{abstract}

Keywords: Teacher talk, teacher discursive moves, Vygostkian perspective, systematic analysis, learning demand

Received: 31.03 .2020

Accepted: 20.08 .2020

Published: 15.01 .2021

\section{INTRODUCTION}

This study aimed at attaining a critical review of teacher discursive moves (TDMs) for science teaching and learning in the context of Vygotskian perspective. The review was framed by two fundamental concepts: (science) learning and teaching in Vygotskian manner. In a Vygotskian sense, learning denotes the acquisition of an alternative (social) language incorporating specific thinking and talking styles (Vygotsky, 1978). In science classrooms, meaning making of a concept can be achieved in two planes: intermental (social plane) and intramental (cognitive plane). On the intermental plane, members of a specified community perform various social languages (Bakhtin, 1986) and other semiotic mechanisms (such as symbols, diagrams, graphics, gestures, intonations, and mimicking) as in the forms of speech genres (Wertsch, 1991) to produce a situated meaning (Rogoff, 1990; Vygotsky, 1981; Vygotsky, 1978). Then, following the internalisation of the reproduced phenomena among group members, individual thinking is played out on the intramental plane (Vygotsky, 1981; Vygotsky, 1978). In this context, learning phenomena is thought to be actualized from social cognitive systems, for instance, from learning communities as classrooms to individual cognition of a member of that community (Lemke, 1990; Mercer \& Dawes, 2014).

For the intermental plane, Vygotsky (1987) proposed two terms: spontaneous and scientific concepts. The former ones "are developed through everyday experience and communication and are formed aside from any process aimed specifically at mastering them" (Scott 1997, p. 16). Vygotsky (1987) clarified that scientific concepts can be formed through formal instruction as "the birth of the scientific concept begins not with an immediate encounter with things but with a mediated relationship to the object" (p. 219). The existence of the spontaneous and scientific concepts confirms that there can be different thinking and talking approaches to a phenomenon for different groups. In an instructional context, learners may hold and apply their spontaneous concepts in meaning making a phenomenon, while scientists consider and operate a more distinctive jargon specifying their alternative thinking. Bakhtin (1986) explicated a social language as "a discourse peculiar to a specific stratum of society (professional, age group, etc.) within a given system at a given time" (Holquist and Emerson 1981, p. 430). Aforesaid distinctiveness between the social languages is also valid for science instruction (Leach and Scott 2002, Scott 1998). Students may come to classrooms with their spontaneous concepts ("Plants feed on the earth" or "I've consumed my energy today") that can be 
different from or alternative to the thinking and talking of experts ("Plants produce their nutrients through photosynthesis" or "Energy can only be transformed into other forms of energies").

Obviously, there are two (distinctive) social languages that must be taken into consideration by science teachers: everyday social languages of learners and social languages of scientists (Leach and Scott 2002, Scott 1998). When the existences of these two distinctive social languages are infused into the instructional contexts, there will be inevitable instructional tension for science teachers. To manage this discursive tension, science teachers' pedagogical decisions and accompanied actions as TDMs attach importance. A science teacher should consider the social languages that learners bring to the class and, for the curricular reality, s/he has to convey a specific content to students and the curricular contents are inherently closer to the social languages of scientists as in the form of social languages of the school science (Leach and Scott 2002, Scott 1998). Science learning therefore means learning an alternative thinking and talking system that can be distinctive from the learners' everyday social languages.

In the sense of this review, science teaching is explicitly related to Zone of the Proximal Development (ZPD) as a Vygotskian concept. The ZPD denotes a consciousness and control of a higher mental process such as science concept learning. This control and holding consciousness are seen at a later stage of development of any mental function (Vygotsky, 1934, p. 90). According to Bruner (1985), a more knowledgeable other who "serves the learner as a vicarious form of consciousness until such a time as the learner is able to master his own action through his own consciousness and control." (p. 24). Over the course of time, learner attains required consciousness and control over the new mental function or conceptualization. Learners can use the new thinking tool that was gained by the true scaffolding of teachers within their ZPD. The author considered aforesaid concepts of Vygostkian learning-teaching as a critical lens to explore and analyse the current research on the TDMs.

\section{Justification of the review}

There are two justifications for this review. The first is the vital place of TDMs for facilitating the processes of teaching and learning science concepts. Second is about a teacher's awareness regarding the expected or emergent influences of the enacted TDMs on the quantities and qualities of student-led cognitive contributions to classroom discourse. There is a substantial body of evidence supporting that students' acquisitions of scientific concepts can be enhanced by means of research-based teaching sequences (e.g., McDermott \& Somers, 1991; Millar, Marechal \& Tiberghien, 1999). A teaching sequence incorporates multifaceted aspects of a classroom activity. It may be characterised by estimating student-led cognitive contributions, teaching activity's streaming, facilitating instructional materials and teacher's scene staging as introducing a scientific story (Leach and Scott 2002). A crucial point regarding establishing teaching sequences can be that how a teacher would consider and put into practice the above-stated aspects of a teaching sequence in a harmonical manner for the sake of the augmentation of the student-led voices.

The first and the most crucial aspect of studies dealing with teaching sequences is that they have been conducted within a process-product paradigm particularly in an experimental sense (e.g., Brown \& Clement, 1991; Viennot \& Rainson, 1999), in which contextual issues associated with teacher-talk and student-talk are often overlooked (Carlsen, 1991; Chin, 2006, 2007; Leach \& Scott, 2002; Scott, 1997). In other words, teaching sequences have been introduced with no reference to TDMs (Westgate \& Hughes, 1997) that encloses any meaningful sequence of teaching (Leach \& Scott, 2002; Scott, 1998). In addition, student-talk together with TDMs have come to prominence since meaning-making is only possible under the circumstances in which teacher and students collectively bring the talk into existence in classrooms to reproduce shared and common knowledge (Mortimer \& Scott, 2003; Ogborn, Kress, Martins, \& McGillicuddy, 1996).

In response, Carlsen (1991) developed a sociolinguistic framework for research into teacher questioning which incorporates three features of questions: the context, content and the responses and reactions. It is possible to accept any evidence-based identification of teaching sequences as illustrative of teacher talk; however, teachers' expertise in their TDMs has more 
importance in this issue in terms of staging those activities for the benefit of the learners (e.g., Leach \& Scott, 2000; Mortimer \& Scott, 2003). Therefore, this extended critical review aims to make the point that research into teaching sequences has been undertaken in an isolated manner ignoring the centrality of TDMs that are indisputably necessary in any teaching sequence.

In Vygostkian sense, it can be asserted that an inanimate teaching sequence can be resurrected by virtue of the relevant enactments of specific TDMs. Moreover, another teaching sequence that is profoundly planned and designed may not be implemented splendidly in the absence of the essential enactments of some specific TDMs. To clarify, scaffolding purposes of a teacher during discursive exchanges that is central to Vygotskian teaching (Driver, Asoko, Leach, Scott, \& Mortimer, 1994) are more possible through displaying appropriate TDMs (Pimentel \& McNeill 2013). To advocate, particularly in science classrooms, it has been widely accepted that teacher and students should be in cooperation with each other to attain meaning making (Crawford, 2000; Driver et al., 1994; Pimentel \& McNeill, 2013; van Zee \& Minstrell, 1997b). The collaboration through intellectual interactions and exchanges may be more instrumental when a teacher arranges his or her discursive moves with a more progressing (van Zee \& Minstrell, 1997b), thought-provoking and challenging (Simon, Erduran \& Osborne, 2006) manner purposing supporting student-led utterances in reaching a consensus during negotiating a scientific concept (Cavagnetto, 2010; Cavagnetto \& Hand, 2012).

A discursive move therefore is a teacher's verbalizations, gestures, intonations, mimics, or positioning in classroom (Chin, 2006, 2007) for the proliferation of the student-led utterances about science phenomenon. Indeed, TDMs can be portrayed as the holistic actions and behaviours of teachers during triggering, maintaining, and finalising a teaching sequence. Actually, by means of specific TDMs, a teacher may invite students to contribute to classroom discourse whereas student-led utterances can also be strictly interrupted in the presence of some other TDMs.

TDMs may therefore involve monologic and dialogic instructional (discursive) purposes. Teachers may not permit students to contribute to classroom conversations while they intensively perform sole monologic TDMs (Mameli \& Molinari, 2013; Lefstein, 2008; Lin, 2007). Monologic TDMs may become invisible when teachers supply information and evaluate students' ideas against the canonical knowledge of science (Chin, 2007; McMahon, 2012). In addition, teachers may pool, summarize, and consolidate the ideas that were previously negotiated during classroom discourse (van Booven, 2015; Oh \& Campbell, 2013). Dialogic TDMs may aim at facilitating students' verbal interactions and intellectual contributions to the classroom conversations (Burns \& Myhill, 2004; Mercer, 2010; Mortimer \& Scott, 2003) Dialogic TDMs can be exemplified as:

- clarifying, elaborating, and probing learners' ideas (Pimentel \& McNeill, 2013),

- focusing learners on focal aspects of activity and encourage them to monitor the classroom events (Christodoulou \& Osborne, 2014; van Zee \& Minstrell, 1997a),

- enacting reflective discourse by throwing the responsibility of thinking back to the students (van Zee \& Minstrell, 1997b; Crawford, 2000; Pimentel \& McNeill, 2013)

- engaging students to put the legitimizations of the evaluation of other's conceptual or procedural discourse (e.g., Christodoulou \& Osborne, 2014; van Zee \& Minstrell, 1997a),

- $\quad$ acting as challenger and seeking for justified reasoning (e.g., Chin, 2006; Christodoulou \& Osborne, 2014; Jadallah et al., 2011; McMahon, 2012; Simon, Erduran \& Osborne, 2006).

In the last analysis, if the learning is derived from intermental plane to intramental plane, and in science education literature, if a teacher has accountabilities for both putting student-led utterances forward and highlighting the concepts or languages of school science (atoms, electrons, molecules, ecology, particles, or acceleration), substantially specific combinations of the TDMs should be considered and enacted by teachers. To support, particularly for the social plane of the classroom, TDMs can be considered as among the most important components in appreciating teachers' instructional attempts to guide learners for authentic meaning making for their further internalisations (Lemke, 1990; Mortimer \& Scott, 2003). Thus, there may be a principal tension for teachers in performing TDMs during managing the streaming of classroom discourse. Thus, in addition to planning and designing sole materialistic teaching sequences, 
critical analysis of TDMs should be conceived as a fundamental factor for the current aims of science education.

Secondly, teachers may not have a comprehension or awareness of, for instance, the structural components (expected discursive streaming) and emergent qualities (unexpected discursive streaming due to social languages of learners) of classroom discourse (Alexander, 2001, 2006; Candela, 2005; Hardman, 2011). In other words, teachers might not possess a pedagogical toolkit that could be used to enhance the productive discursive interactions among student groups to achieve authentic learning experiences (e.g., Wertsch, 1991). However, at least, teachers reading the current research will be familiar with their essential and routine discursive moves. Furthermore, by not ignoring their pedagogical competencies, teachers may also achieve a superficial but a life-sustaining starting point by taking TDMS into consideration when developing teaching sequences (Leach \& Scott, 2000, 2002; Scott, 1997, 1998).Thus, outcomes of this review can be informative for teachers in terms of gaining awareness regarding their essential TDMs in planning, designing and implementing an open-ended science inquiry.

\section{METHODS}

\section{Systematic selection and analysis of the related studies}

This review involves 31 studies examining TDMs in an explicit or direct manner. Selected studies were carried out between 1987 to 2019 and they mostly comprised a fine-grained analysis of TDMs. In this study, considerably strict selection criteria were developed and truly applied. Consequently, limited number of studies were selected to be involved in the analysis procedures. Specific procedures were operated for obtaining the most relevant studies. In searching of related studies, computerized data bases and functional digital operators (e.g., ERIC; Boolean Operator) were used to filter out the related studies that were published after 1985.

\section{Percantages across the sources}

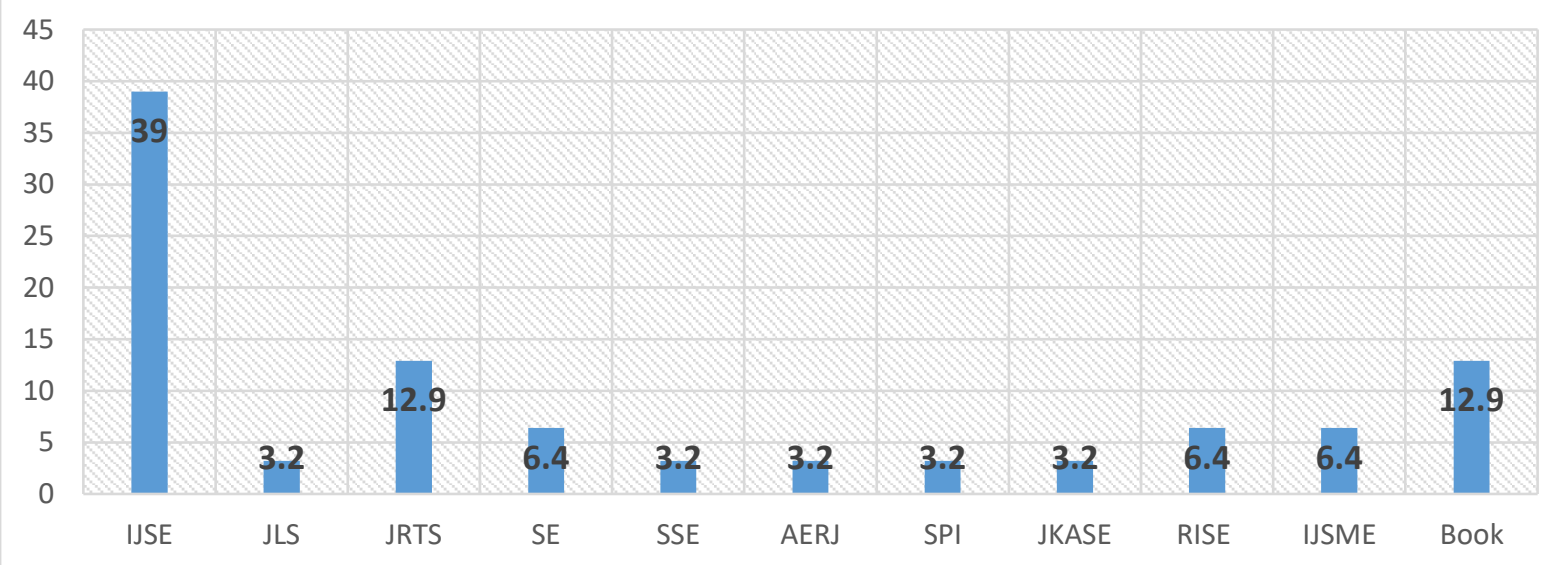

*IJSE: International Journal of Science Education; JLS: The Journal of the Learning Sciences; JRTS: Journal of Research in Science Teaching; SE: Science Education; SSE: Studies in Science Education; AERJ: American Educational Research Journal: SPI: Social Psychology International; JKASE: Journal of Korean Association for Science Education; RISE: Research in Science Education; IJSME: International Journal Science \& Mathematics Education

FIGURE 1. Distribution of the selected studies in terms of the source types*

The search was conducted in 2019 through considering specific keywords: "classroom discourse", "teacher discursive moves", "teacher discursive roles", "science education", "teacher talk", "science classroom discourse", "discursive mode", "discursive action", "classroom exchanges", "classroom interactions" or other synonyms or related terms. Primary and secondary references were limited to "Academic Journals" and "Books \& Book Chapters". Principally, studies within Academic Journals (e.g., International Journal of Science Education; Journal of Research in Science Teaching; 
Studies in Science Education) were selected according to their current (higher) impact factors or reputations in the field. Figure 1 displays the relative percentages of the selected studies from Academic Journals of science education. As seen, most of the selected studies were published in International Journal of Science Education that has been acknowledged as a specific journal and promoted by science teachers and scholars in the field. Moreover, the author considered diversity pertaining types of the determined Journals to grasp the different scholar-led voices. Figure 2 shows another aspect of the selection procedures. As mentioned, in the pool, there were studies of nearly 32 years. As shown in Figure 2, the trend-line confirms an incremental tendency from the early years of researching into the TDMs to the recent efforts of the scholars.

For a systematic sampling of the current research on the TDMs, the author strictly took several the aspects of the selected studies into account. At first, selected studies were devoted to improvement the theory of science education. Secondly, the studies were particularly selected by checking a criterion whether they explored any sets of TDMs in an explicit manner. Thirdly, there was a diversification regarding the instructional approaches (implementations of in-class activities) of the selected studies. Some studies conducted both teacher-centred and studentcentred modes of teaching (e.g., Chin, 2006, 2007), and several studies' implementations were the examples of learner-centred teaching (e.g., Christodoulou \& Osborne, 2014; Kawalkar \& Vijapurkar, 2013; Mortimer \& Scott, 2003; Pimentel \& McNeill, 2013).

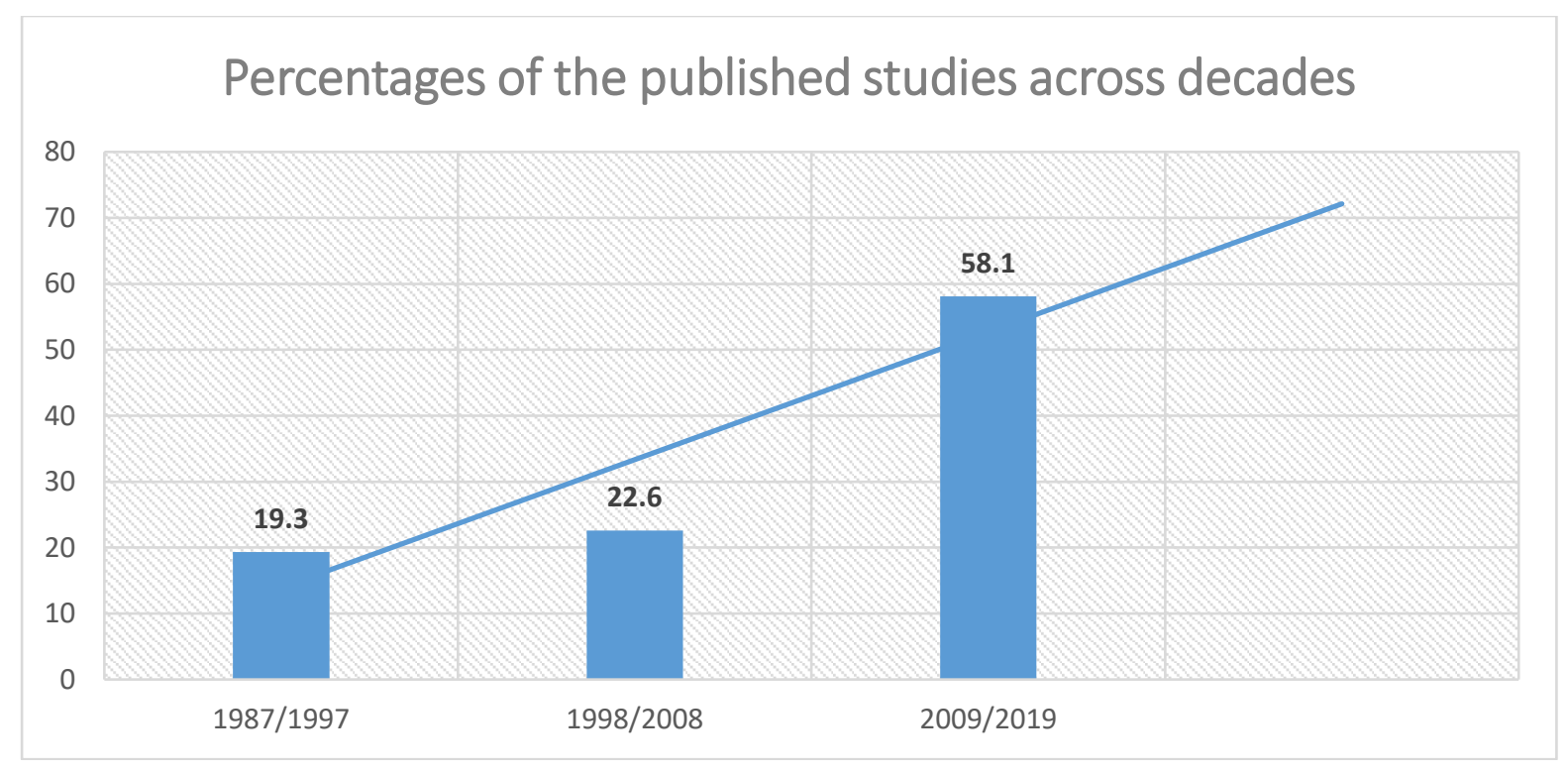

FIGURE 2. Quantitative changes in the selected studies between 1987-2019

Fourthly, it was also a matter of selection whether the pooled studies incorporated diversifying participants as students varying in terms of academic grades such as secondary science classrooms (e.g., Mortimer \& Scott, 2003) or middle school level (e.g., Bansal, 2018; Simon et al. 2006; Soysal, 2018; 2019; Tytler \& Aranda, 2015). Finally, techniques of analysis of the TDMs taken by the pooled studies were another criterion. To explicate, some studies extracted TDMs by analysing episodes in an interpretivist sense (e.g., Chin, 2006, 2007; Mortimer and Scott, 2003), and other studies operated (lag) sequential analysis techniques to attain a systematic observation through coding and counting (e.g., Jadallah et al. 2011).

The systematic determination of the studies serviced two purposes. Firstly, there was a better sampling of the related studies that were considerably representative as the selected works reflected both past and current streaming of the research on the TDMs. Secondly, the systematic approach was useful in re-categorising the detected TDMs around newly invited theoretical frames, thus, incorporated a pragmatist approach in determining and analysing an intensifying research area. 


\section{The development of analysis procedures}

The analysis of the extracted TDMs in the determined studies incorporated three stages.

Stage-1: Establishing the pool of the TDMs

\begin{tabular}{|c|c|c|c|c|c|}
\hline \multicolumn{6}{|c|}{$\begin{array}{c}\text { POOLS OF THE STATED TEACHER DISCURSIVE MOVES } \\
\text { 0: NON-INTERACTIVE / AUTHORITATIVE; 1: INTERACTIVE / AUTHORITATIVE; } 2: \\
\text { NON-INTERACTIVE / DIALOGIC; } \\
\text { 3: INTERACTIVE / DIALOGIC }\end{array}$} \\
\hline Study & Defined or suggested TDMs & 0 & 1 & 2 & 3 \\
\hline \multirow{6}{*}{$\begin{array}{l}\text { 1. Edwards \& } \\
\text { Mercer } \\
(1987)\end{array}$} & Elicitation of pupils' contributions & & & & $\mathrm{X}$ \\
\hline & Marking the knowledge as significant and joint & & $\mathrm{X}$ & & \\
\hline & Cued elicitation of pupils' contribution & & $\mathrm{X}$ & & \\
\hline & Paraphrasing pupils' contributions & & & & $\mathrm{X}$ \\
\hline & Offering reconstructive recaps & & $\mathrm{X}$ & & \\
\hline & Direct lecturing & $\mathrm{X}$ & & & \\
\hline \multirow{6}{*}{$\begin{array}{l}\text { 2.Lemke } \\
(1990)\end{array}$} & Cued elicitation & & $\mathrm{X}$ & & \\
\hline & Selection and modification of pupils' responses & & $\mathrm{X}$ & & \\
\hline & Presenting logical expositions & $\mathrm{X}$ & & & \\
\hline & Teacher-led narrations & $\mathrm{X}$ & & & \\
\hline & Selective summary & & & $\mathrm{X}$ & \\
\hline & Foregrounding and backgrounding & & & & $\mathrm{X}$ \\
\hline
\end{tabular}

FIGURE 3. A coding sample representing identifying communicative approaches

A piece of the list or pool of the selected TDMs can be seen in Figure 3. The author first perused the selected studies and clearly dissected stated TDMs. Thus, it became possible to establish an enlarged list of the TDMs to provide a panoramic exploration of the several TDMs by comparing them each other during coding.

\section{Stage-2: Determining the tendency of the TDMs for re-categorisation}

To attain a re-categorisation of the stated TDMs, a widely acknowledged framework developed by Mortimer and Scott (2003) was used to characterize and analyse the TDMs. The framework was structured through a longitudinal research program (e.g., Mortimer, 1998; Mortimer \& Scott, 2000; Scott, 1998) and incorporates five distinctive and inter-related aspects:

- Teaching purposes - discussing, negotiating, exploring, working on and reviewing regarding the ideas of the students,

- Content - a specific knowledge field in which discursive events occur,

- Communicative approaches - identifying teaching episode in terms of whether it is dialogically or monologically oriented and placed at the heart of the framework,

- Patterns of interactions - Initiate-Response-Evaluate (IRE) triadic pattern or I-R-P-R-P-Ras a chain of interaction that remains open without a final evaluation; I-Rs1-Rs2-Rs3: an example of a student-initiated sequence that starts with a question, or when different students respond to the same question from the teacher (P: prompt; R: response; Rsn: students' response),

- $\quad$ Teacher interventions - the teacher's discursive moves in meaning making in classrooms.

The centralized aspect of the framework Communicative Approach was taken into account in categorizing the TDMs. In addition, the Teaching Purposes and Content aspects of the framework were also considered to interpret the TDMs. The communicative approach consists of two basic dimensions; non-interactive/interactive and dialogic/authoritative (see also Table 1) which are briefly described below. 
Table 1. Four Classes of Communicative Approaches

\begin{tabular}{ccc}
\hline & INTERACTIVE & NONINTERACTIVE \\
\hline DIALOGIC & Interactive-dialogic & Noninteractive-dialogic \\
\hline AUTHORITATIVE & Interactive/authoritative & Noninteractive/authoritative \\
\hline (Modified from Scott, Mortimer, \& Aguiar, 2006) &
\end{tabular}

A. Interactive/dialogic: The teacher and students consider a range of ideas. If the level of interanimation (i.e., in-depth negotiation of ideas) is high, they pose genuine questions as they explore and work on different points of view. If the level of interanimation is low, different ideas are simply presented.

B. Non-interactive/dialogic: The teacher revisits and summarizes different points of view, either by simply listing them (low interanimation) or exploring similarities and differences (high interanimation).

C. Interactive/authoritative: The teacher focuses on one specific point of view and leads students through a question and answer routine with the aim of establishing and consolidating that point of view.

D. Non-interactive/authoritative: The teacher presents a specific point of view (Scott, Mortimer \& Aguiar, 2006, p. 611).

Dimensions of the communicative approach can be used to characterise classroom discourse into dialogic or monologic or whether the discursive interactions are actualised on a teacher-student or student-student basis (Mortimer \& Scott, 2003). Furthermore, types of communicative approach can be used to determine whether discursive events among the learning group pass through knowledge-transmission or knowledge co-construction modes of teaching (e.g. McMahon, 2012). Additionally, the interanimation of ideas is emphasized in the communicative approach particularly for the dialogic dimensions. The interanimation of ideas represents, at one extreme, low interanimation, in which the teacher may gather students' ideas and pool them, for instance, presenting them on the board; however, the teacher makes no attempt to elaborate, compare, contrast or challenge any of the ideas. At the other extreme, in high interanimation, "the teacher might adopt an approach which involves trying to establish how the ideas relate to one another" (Scott et al., 2006, p. 610).

In Figure 3, a sample analysis is displayed. As seen in Figure 3, there are two sample studies. The listed TDMs were re-categorised according to the communicative approach dimensions. For instance, Edwards and Mercer (1987) proposed elicitation of students' contributions discursive move. This discursive move was coded as interactive/dialogic in terms of communicative approach. To explain, as Edwards and Mercer (1987) indicated, a teacher may enact elicitation move to clarify, probe and discern the background reasoning, meaning or intention embedded in student-led utterance(s). For elicitation move, there would be an interaction between teacher and students. In addition, while a teacher tries to capture the background meaning of the student-led responses, the exchanges would be dialogic. To explicate, the discursive intention of an elicitation will be servicing probing the scope of the provided response. In other words, there are no intentions for implying evaluating a proposed response, ignoring a student-led viewpoint, or selecting an assertion over another on the side of the teacher, when s/he tries to elicit the student-led responses. In this sense, the teacher only collects and pools the student-led utterances by means of low interanimation to clarify the scope of the student-led ideas. Beyond, a teacher enacting elicitation move only tries to understand and comprehend what his or her students had previously tried to mention about.

For another discursive move, marking the knowledge as significant and joint, a teacher may hold a different discursive intention compare to the former one. Once a teacher marks the knowledge as significant and joint, s/he gives a meta-message to students that they provided a response that was closer to point the teacher has tried to reach. Thus, by marking the knowledge as significant and joint, a teacher is liable to select or make prominent a particular response over another since that is more associated with the social languages of school science. In conclusion, 
even though there is an interaction between teacher and students, there is an explicit selection of some specific utterances and an implicit elimination of some specific student-led responses. Thus, marking the knowledge as significant and joint move was coded as interactive/authoritative. In Figure 3, there are other TDMs that were coded according to the four aspects of the communicative approach.

Two methodological precautions were considered for an internally consistent coding procedure. First, to discern a stated discursive move from others, a back-and-forth (zig-zag) process was undertaken. To explicate, in comparing each TDMs with others, the author returned to a study (main text) to comprehend whether a discursive move was conceived in a different way from lens of the author(s) of the study. Then, the author utilised the authors' visions and considered these visions for the discernment processes. For instance, as seen in Figure 3, there are common and separated codes (types of communicative approach) for the two different studies. However, there would be contextual or study-based differences between the TDMs coded in the same way. Thus, to detect the study-based influences in terms of separating a discursive move from another or homologising two or more TDMs, a comparative analysis was continuously and rigorously maintained until ensuring that all analytical codes (TDMs) were compared and contrasted each other to detect tiniest nuances or resemblances. In the last analysis, the author's vision was framed by the data pool and assigned TDMs were evaluated against other assigned codes to detect possible study-based differences or resemblances.

Secondly, as cautiously signalled by Scott et al. (2006) and Mortimer and Scott (2003), an utterance of a teacher may not be simply categorised as dialogic or authoritative. However, in a study by van Booven (2015), it is accepted that "[A]n isolated teacher move cannot be considered definitively dialogic or authoritative independent of the student response, I propose that certain teacher questions, by virtue of their structure and inferred purpose, can display an orientation to either dialogicity or authoritativeness, which the student(s) may either ratify or resist with their responses." (p. 1187, original emphases) and similar orientations were also acknowledged in the current review. To ensure this, sample excerpts inserted in the studies (e.g. Mortimer \& Scott, 2003) were also paid attention to determine the communicative orientations of the explored discursive moves.

\section{Stage-3: Comprising categories of the TDMs within the aspects of the communicative approach}

It was the final round of the analysis process in which previously coded discursive moves around each dimension of the communicative approach were collapsed into the relevant higher-order categories for a broader representation of the explored TDMs. As mentioned, in the first two stages, whole subordinate or analytically-oriented codes were categorized into the following four aspects of the communicative approach; non-interactive authoritative (NA), interactiveauthoritative (IA), non-interactive dialogic (ND) and interactive-dialogic (ID). In the third round of the analysis, several codes that were gathered under four aspects of communicative approach were also collapsed into broader categories to redefine the TDMs in a wider sense. In this context, indications of major discursive moves (e.g., Shaping Ideas) and subordinate roles (e.g., paraphrasing a student's response) that had previously been explored by other researchers (e.g., Mortimer \& Scott, 2003) were beneficial in denominating higher-order categories. Less than $10 \%$ ( $n=19$ ) of all the codes (the TDMs) were specified as outliers and could not be categorized since there were contextual and content-related differences among the studies involved. A detailed demonstration of the sample codes and higher-order categories can be seen in Table 3 .

\section{RESULTS}

\section{Initial Findings for the TDMs}

After a closer look at the reviewed studies, several codes $(n=240)$ were constituted. 21 categories were determined, most of which concerned the interactive-dialogic communicative approach (n $=11$, see Table 2). Fewer categories of TDMs were found to consist of non-interactive 
communicative approaches. In accordance with these findings, genuine discursive interactions among teachers may allow for more varied discursive events independent from whether they are either dialogically- or authoritatively-oriented. In other words, augmentation in interactive discursive events requires teachers to have more diversified TDMs.

Furthermore, the studies reported a large number of TDMs within the interactive-dialogic communicative approach. The reviewed studies showed that over the course of the teacher's inclass implementations, learners were involved in either doing-science or doing-mathematics processes. The in-class activities presented in the studies were depicted as authentically openended. There were no recipe-type, step-by-step procedures and the students conducted their own research (e.g., Crawford, 2000; Roychoudhury \& Roth, 1996).

Table 2. Frequencies of Teacher Discursive Utterances

\begin{tabular}{ccccc}
\hline Communicative approach & Codes $(\boldsymbol{f})$ & $\boldsymbol{\%}$ & Categories $(\boldsymbol{f})$ & $\boldsymbol{\%}$ \\
\hline NA & 19 & 8 & 2 & 9 \\
\hline IA & 51 & 20 & 5 & 25 \\
\hline ND & 20 & 9 & 2 & 52 \\
\hline ID & 131 & 55 & 11 & 5 \\
\hline Others & 19 & 8 & 1 & 100 \\
\hline Totals & 240 & 100 & 21 & 9 \\
\hline
\end{tabular}

Additionally, there are classroom discursive events that may not suit the teachers' previously determined teaching agenda (van Zee \& Minstrell, 1997a; 1997b). In an open-inquiry session, teachers should embrace diverse voices (whether scientific or not) from learners (Leach \& Scott, 1995,2002 ) that may be substantially distinct from the conceptualizations of school science. As shown in the initial frequencies, teachers therefore can undertake a wide variety of TDMs in response to numerous, on-moment fluctuant discursive utterances of learners observed in whole classrooms when the multivocality is assimilated as a teaching mode by teachers (Bansal, 2018; Lefstein, 2008; Roth, 1996; Roychoudhury \& Roth, 1996).

\section{Categorisations of TDMs regarding communicative approaches}

A potential correspondence between communicative approaches and categories of the TDMs is given in Table 3. At first glance, it seems to affirm a well-supported matching between communicative approaches (teaching modes' orientation) and related TDMs. Furthermore, there also seems to be a hierarchy among the TDMs from more monologic moves to more dialogic ones. For example, it is conceivable that giving information directly to students (e.g., Chin, 2007; Edwards \& Mercer, 1987; Lemke, 1990) is discursively simpler and attainable for a teacher compared to acting as challenger, discussant and negotiator (e.g., Chin, 2006; McMahon, 2012; Simon, Erduran \& Osborne, 2006). This action may be regarded as taking the easy way out compared to encouraging students to monitor whole classroom events (e.g., Bansal, 2018; Tabach et al., 2019; van Zee \& Minstrell, 1997a). Therefore, it is rational to recognize the gradual qualities of the TDMs in the above-mentioned sense. However, by critically considering the reviewed studies, another noteworthy hierarchy can be extracted by characterising incremental qualities of the TDMs.

\section{A newer lens: “Gradual qualities" of the TDMs}

With reference to an orthodox view, more monologic TDMs are associated with the knowledgetransmission modes of teaching whereas the more dialogic TDMs are linked to the coconstruction of knowledge (e.g., Crawford, 2000; NRC, 1996). It is also estimated that there may be a graduation of qualities or a hierarchy in TDMs because in responding to unforeseen instances in the classroom in the presence of deviations from the teachers' prescriptive agenda (social 
languages of school science or social languages of scientists/experts), dialogic discursive exchanges and interactions may be required as rather complex TDMs (e.g. van Zee \& Minstrell, 1997a, 1997b). However, the critical review of many studies culminated in another instance that characterises the gradual qualities of the TDMs. In this context, a discursive thinking tool comprising four graduations of the qualities of the TDMs has been developed. These graduations range from Level 0 to Level 3 as described below and were derived from the reviewed studies.

\section{Level 0 TDMs}

In this initial and naive level, teachers may prepare strategies comprising modest monologic sequences favouring a knowledge-transmission teaching style. The examples of Level 0 moves are well defined in the literature as teachers directly give information as a knowledge supplier, (e.g., Chin, 2007; Edwards \& Mercer, 1987; Lemke, 1990; McMahon, 2012) or teachers make evaluations of the responses of students based on the canonical knowledge of science (e.g., Chin, 2006; Oliveira, 2010; Pimentel \& McNeill, 2013; Soysal, 2018; 2019; van Booven, 2015). As a rationale, more monologic teacher discursive roles are associated with the knowledge transmission modes of teaching.

\section{Level 1 TDMs}

At this level most of the time, teachers perform more dialogic discursive utterances in an intentional sense. From the literature review in the current study, more than half the TDMs were appraised within the frame of the interactive/dialogic communicative approach. Within this level, there were only dialogic TDMs and even though classroom discourse is interactive in nature; there is no deliberate teacher attempts to develop student-generated ideas. However, in a dialectical sense, the existence of true dialogism considerably depends upon the presence of more monologic discursive interactions in addition to those of a dialogic nature (Engle \& Conant, 2002; Leach \& Scott, 2000; Mortimer \& Machado, 2000). As mentioned, in any classroom context, there may be distinctive social languages (Bakhtin, 1986; Wertsch, 1991). The actualisations of the everyday social languages of learners require more dialogic interactions. However, in grasping the discourses of school science, teachers also must undertake more monologic moves (e.g., Aguiar, et al., 2010; Mortimer \& Scott, 2003). Thus, meaning making is mostly literal if the learning processes are initiated by considering students who are expected to generate their own meaning by appropriating and applying alternative social languages (Bruner, 1985; Kress et al., 1998; Ogborn et al., 1996; Scott, 1997; Sutton, 1996). Following student-led initiations and on-going negotiations of the learned phenomena, social languages of school science would be spoken in a more monologic manner (e.g., Aguiar, et al., 2010; Mortimer \& Scott, 2003; Scott, 1997, 1998).

Moreover, plain dialogic interactions do not promote the genuine co-construction of knowledge among learners since according to Molinari, Mameli and Gnisci (2013);

\footnotetext{
"[C]o-constructive sequences, characterized by requests of clarification, use of examples, and solicitation of reformulations or reflections, are a different way, as compared to dialogic sequences, to foster dialogue and participation in class: while dialogic sequences unfold in a free and open interaction, co-constructive ones are more structured and controlled by the teacher who, nevertheless, does not 'abuse' her role as primary knower and makes the effort to guide the children's development of deduction skills, reasoning, and thinking. These sequences are, therefore, fruitful occasions for constructing knowledge and encouraging the children's active participation in the discourse." (p. 425).
}

As inferred from the interpretation of Molinari et al. (2013), pervasive dialogic TDMs may not produce a true co-construction of knowledge in the absence of more monologic TDMs. This means that when teachers initiate a sequence from the everyday social languages of learners and continue with school science social languages, the acquisition of scientific concepts is more viable 
with the support of more monologic TDMs (Mortimer, 1998; Scott, 1997). If this is the case, there should be a blurred genre accounting for the TDMs in the co-construction of knowledge and this means that both more monologic and more dialogic TDMs should be appropriately and simultaneously managed by the teachers in making meaning (Mortimer, 1998; Mortimer \& Scott, 2003; Scott, 1997; Scott \& Mortimer, 2002). In other words, when more monologic and more dialogic TDMs are isolated and their dialectical interactions are disclaimed, they become simplified.

Table 3. Categorizations of Teacher Discursive Moves

\begin{tabular}{|c|c|c|c|}
\hline $\begin{array}{c}\text { Communicative } \\
\text { approach }\end{array}$ & $\begin{array}{c}\text { Categories of teacher } \\
\text { discursive moves }\end{array}$ & Some examples codes & Sample studies \\
\hline \multicolumn{4}{|c|}{ More monologically oriented discursive moves } \\
\hline \multirow[b]{2}{*}{$\begin{array}{l}\text { Noninteractive } \\
\text { authoritative }\end{array}$} & $\begin{array}{l}\text { 1.Teacher gives } \\
\text { information }\end{array}$ & $\begin{array}{l}\text { Direct lecturing, logical } \\
\text { expositions, verbal cloze }\end{array}$ & $\begin{array}{l}\text { Edwards \& Mercer (1987); } \\
\text { Lemke (1990); Chin (2007); } \\
\text { McMahon (2012); Soysal } \\
(2018 ; 2019)\end{array}$ \\
\hline & $\begin{array}{l}\text { 2.Teacher evaluates } \\
\text { students' responses } \\
\text { based on the } \\
\text { canonical knowledge } \\
\text { of science }\end{array}$ & $\begin{array}{l}\text { Comprehension checks, } \\
\text { cutoff, affirmation-cum- } \\
\text { direct instruction }\end{array}$ & $\begin{array}{c}\text { Oliveira (2010); Chin } \\
\text { (2006); van Booven (2015); } \\
\text { Pimentel \& McNeill (2013) }\end{array}$ \\
\hline \multirow{4}{*}{$\begin{array}{c}\text { Interactive } \\
\text { authoritative }\end{array}$} & 3.Eliciting & $\begin{array}{l}\text { Elicitation of pupils' } \\
\text { contributions, 'cued } \\
\text { elicitation }\end{array}$ & $\begin{array}{c}\text { Kawalkar \& Vijapurkar } \\
\text { (2013); van Booven (2015); } \\
\text { Lemke (1990); Soysal } \\
\text { (2018; 2019); Grinath \& } \\
\text { Southerland (2019) }\end{array}$ \\
\hline & $\begin{array}{l}\text { 4.Focusing students' } \\
\text { attention on focal } \\
\text { aspects of the activity }\end{array}$ & $\begin{array}{l}\text { Focus attention on a } \\
\text { particular student } \\
\text { response, Introducing the } \\
\text { scientific story by selecting } \\
\text { children to rehearse it }\end{array}$ & $\begin{array}{c}\text { van Zee \& Minstrell } \\
\text { (1997a); Kawalkar \& } \\
\text { Vijapurkar (2013); Oh } \\
\text { (2010); Leach \& Scott } \\
\text { (2002) }\end{array}$ \\
\hline & $\begin{array}{l}\text { 5.Consolidation of } \\
\text { canonical knowledge } \\
\text { of science by teacher }\end{array}$ & $\begin{array}{l}\text { The teacher clarifies the } \\
\text { topic under discussion, } \\
\text { recaps and summaries of } \\
\text { conceptual knowledge }\end{array}$ & $\begin{array}{l}\text { van Booven (2015); Oh \& } \\
\text { Campbell (2013); Louca, } \\
\text { Zacharia, \& Tzialli (2012) }\end{array}$ \\
\hline & $\begin{array}{c}\text { 6. Teacher activates } \\
\text { and expands students' } \\
\text { background } \\
\text { knowledge }\end{array}$ & $\begin{array}{l}\text { Reformulating, expanding } \\
\text { and activating students' } \\
\text { background knowledge }\end{array}$ & $\begin{array}{l}\text { Oh (2010); Oh \& Campbell } \\
\text { (2013) }\end{array}$ \\
\hline \multicolumn{4}{|c|}{ More dialogically oriented discursive moves } \\
\hline \multirow{3}{*}{$\begin{array}{l}\text { Noninteractive } \\
\text { dialogic }\end{array}$} & $\begin{array}{l}\text { 7.Modelling and } \\
\text { rehearsing aspects of } \\
\text { processes of science }\end{array}$ & $\begin{array}{l}\text { Directing students and } \\
\text { helping them develop } \\
\text { experimental strategies }\end{array}$ & $\begin{array}{c}\text { McMahon (2012); Crawford } \\
\text { (2000); Oh (2010); Soysal } \\
(2018 ; 2019)\end{array}$ \\
\hline & $\begin{array}{c}\text { 8.Summaries the } \\
\text { previously occurred } \\
\text { discursive events by } \\
\text { considering multiple } \\
\text { views obtained from } \\
\text { students } \\
\end{array}$ & $\begin{array}{l}\text { Summarize the findings } \\
\text { from a particular } \\
\text { experiment, recap on the } \\
\text { activities of the previous } \\
\text { lesson }\end{array}$ & $\begin{array}{c}\text { Leach \& Scott (2002); } \\
\text { Mortimer \& Scott (2003); } \\
\text { Edwards \& Mercer (1987); } \\
\text { Chin (2007) }\end{array}$ \\
\hline & $\begin{array}{l}\text { 9. Teacher selects and } \\
\text { contextualize the } \\
\text { prominent student } \\
\text { ideas from previously } \\
\text { occurred discursive } \\
\text { events }\end{array}$ & $\begin{array}{l}\text { Selective summary, } \\
\text { selection and modification } \\
\text { of pupils' responses }\end{array}$ & $\begin{array}{l}\text { Leach \& Scott (2002); } \\
\text { Mortimer \& Scott (2003); } \\
\text { McMahon (2012); Soysal } \\
\text { (2018; 2019); Grinath \& } \\
\text { Southerland (2018) }\end{array}$ \\
\hline
\end{tabular}


Table 3 continued...

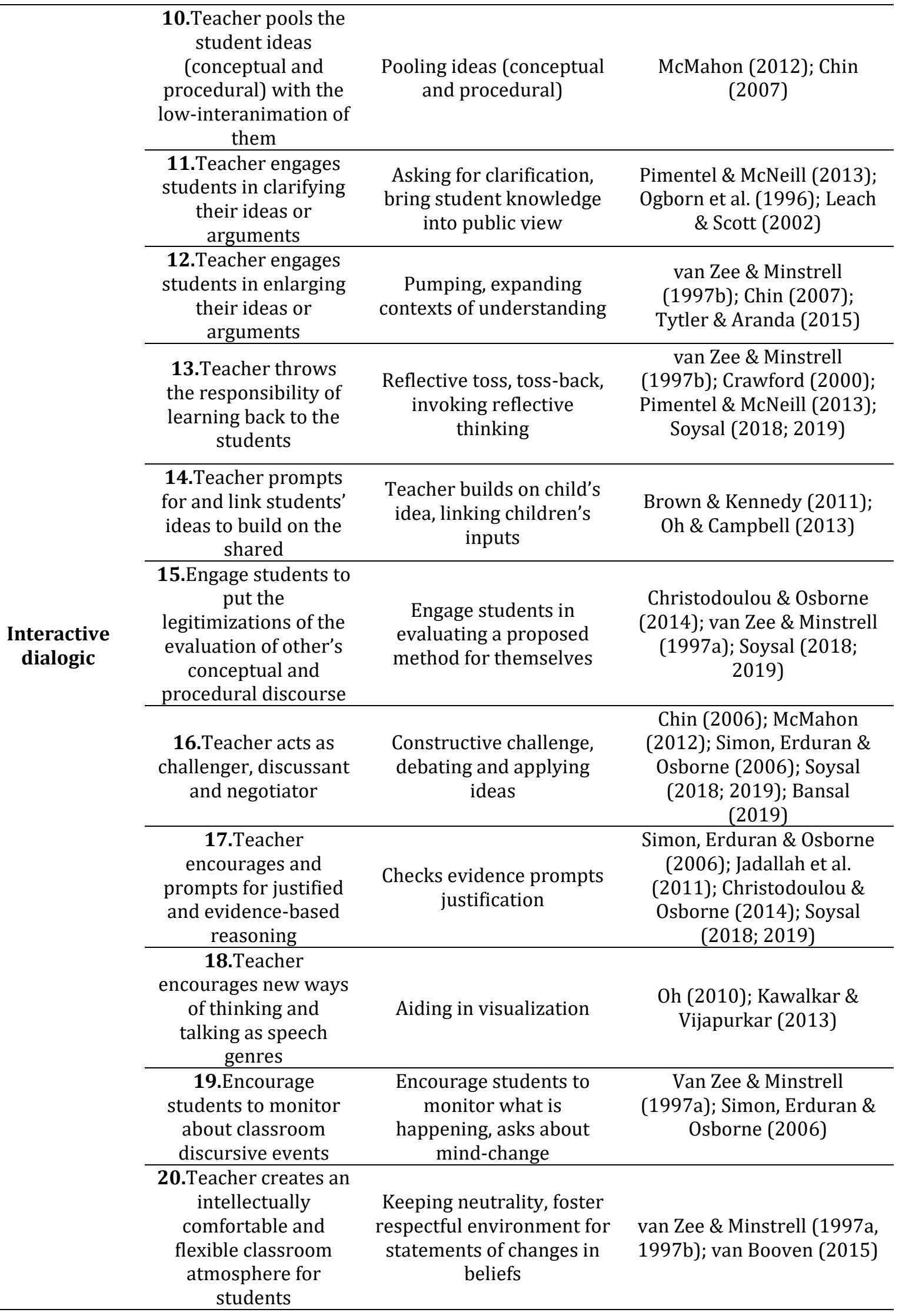


Accomplishing a balanced design that combines more monologic and more dialogic TDMs provides teachers with a mind-stretching pedagogical demand, however (e.g., Zohar, 2006). On one hand, teachers should be able to more closely follow-up learners' everyday thinking and talking (van Zee \& Minstrell, 1997; Mortimer \& Scott, 2003). On the other hand, they should not ignore the orientation of the teaching sequence or the big idea of the lesson that is more related to school science social language (Candela, 2005; Engle \& Conant, 2002; Mameli \& Molinari, 2013; Scott et al., 2006).

\section{Level 2 TDMs}

At this level, teachers can substitute their discursively insufficient aspects of Level 1 TDMs with more monologic and more dialogic discursive moves. This allows the teacher to attain a perfect discursive balance involving the rhythm of classroom discourse by taking learners' learning demand into account (Aguiar, Mortimer, \& Scott, 2010; Leach \& Scott, 2000, 2002; Scott, 1997, 1998). The elements of this balanced approach are interpreted below in the sense of relevant theoretical frames.

The teaching purpose is to explore or discuss: Teachers in a teaching sequence may begin by gathering students' ideas regarding the content under discussion through low-interanimation of ideas as in the form of cumulative talk (Mercer, 2000). This indicates that there are no deeper negotiations concerning the ideas generated by students (e.g., Scott et al., 2006). In this context, a teacher may only collect and list the student-led ideas. In this review, a prominent discursive move representing cumulative talk is that the teacher pools the student ideas (e.g., McMahon, 2012; see also Table 3). In this situation, there is a gradual decontextualisation as the teacher guides student talk away from the descriptions of scientific events or rules (Mortimer \& Scott, 2003). Rather, the teacher starts with students' ideas (social languages) and tends to guide them to a transformation in which the learned phenomena from the here-and-know of everyday views is relocated to the generalizable statements of science (Scott, 1998). When this is the case, teacher should implement TDMs which are embedded in interactive/dialogic communicative approach (Table 3) in order to explore or discuss students' raw interpretations, for instance, by engaging students in clarifying (e.g., van Zee \& Minstrell, 1997a) and enlarging (e.g., Chin, 2006, 2007) their ideas or arguments, throwing the responsibility of thinking and learning back to students (Crawford, 2000; van Zee \& Minstrell, 1997b), acting as challenger, discussant and negotiator (e.g., McMahon, 2012; Simon et al., 2006), or encouraging and prompting students for justified and evidence-based reasoning (Christodoulou \& Osborne, 2014; Jadallah et al., 2011; see also Table 3 for detailed ones).

The teaching purpose is to work with learners' ideas: After the initial negotiations concerning learners' ideas, the teacher engages in a process referred to as one of recontextualisation, in the sense of moving from everyday language to that of the scientific world. In this case, the teacher does not implement explorative interactive/dialogic TDMs (see also Table 3); rather, she may choose to undertake interactive/authoritative discursive strategies in order to work with students' ideas (Mortimer \& Scott, 2003). In this manner, teachers may offer cued elicitations in order to deliver the message to students that "you argued something neater and closer to the content in my lesson plan" that is matched with the social languages of school science (e.g., Grinath \& Southerland, 2019; Kawalkar \& Vijapurkar, 2013; Soysal, 2018; 2019; van Booven, 2015). Moreover, teachers may focus students' attention on main aspects of the activity (e.g., Kawalkar \& Vijapurkar, 2013; Oh, 2010) by modelling and rehearsing aspects of processes of science (e.g., McMahon, 2012) in order to consolidate the canonical knowledge of science (Crawford, 2000; McMahon, 2012; Oh, 2010, see also Table 3). To sum up, it is the essence of science teaching and the unique job of science teachers to introduce and recognize new ideas, and to handle the scientific story. Authoritative or more monologic TDMs are, therefore, equally important and fundamental discursive moves for effective discursive interactions (Aguiar, Mortimer, \& Scott, 2010; Leach \& Scott, 2000, 2002).

The teaching purpose is to wrap-up the previously created discourse: At the end of the staging the scientific story with students, teachers may also apply TDMs framed in a non- 
interactive/authoritative communicative approach (see also Table 3) to wrap-up the previously negotiated ideas (Mortimer \& Scott, 2003). In this review, two categories of the TDMs were redefined. Under the heading "teacher gives information" were included the following moves; direct lecturing (e.g., Edwards \& Mercer, 1987), presenting logical expositions (e.g., Lemke, 1990), providing narratives (e.g., Scott, 1998), and posing verbal cloze (e.g., Chin, 2007). For the second category, the teacher makes assessments of student-led utterances based on the canonical knowledge of science through comprehension checks (e.g., Oliveira, 2012), direct affirmation (e.g., van Booven, 2015) or assessing and advising students (Oh, 2005; also see Table 3). At this point in a teaching sequence, since the students had already argued the content and supplied ideas using their everyday social languages, they then move on to the worlds of scientific thinking and talking. It may be more appropriate to enact the TDMs within the noninteractive/authoritative approach in reviewing or wrapping-up previously created discourse (Mortimer \& Scott, 2003). As illustrated by Edwards and Mercer (1987), the previously created discourse stands for "a -we- voice" often used in such TDMs incorporating reviewing and summarising progression and maintaining of the scientific story that had been owned by the students. The instructional implication of this we voice is that students may reproduce a shared and common understanding through the collaboration of teacher's scaffolding efforts (Mercer, 1995; Mortimer, 1998; Scott, 1998; van Zee \& Minstrell, 1997b; Wertsch, 1998). Thus, there is a clear rhythm of science teaching over the course of the cycles of explore, work with and review in which teachers act out their TDMs in a way which is both more monologic, and more dialogic utterances are obligatorily maintained in a holistic discursive manner.

\section{Contents of school science require diverse combined enactments of the TDMs}

Another point featured in the literature may be students' learning demand, which offers insights into the Level 2 TDMs. As mentioned, according to Vygotsky (1978), higher mental functioning in individuals derives from social processes. From this perspective, language and thought are intimately related since "In the first instance language and other semiotic mechanisms (such as mathematical symbols, diagrams, gesture, stance) provide the means for ideas to be talked through and communicated on the social or intermental plane and, following the process of internalization, language and other semiotic modes provide the tools for individual thinking." (Leach \& Scott, 2002, p. 120). As aforesaid, Vygotsky (1987) defined two thematic contents to characterise the interaction between thought and language as everyday concepts (i.e., involving students' ideas without conscious) and scientific concepts (i.e., systematically established terminology). These contents were redefined by Bakhtin (1986) within the frame of distinguished social languages used by specific communities (science learners) for specified aims (conceptualisation of science concepts; or thinking-talking similar to a scientist). In this context, there are distinctions among social languages of school science, scientists' social languages and everyday languages of learners (Leach \& Scott, 2002; Scott, 1998). It is accepted that the professionals of science who generate knowledge of science in a systematic way and the actors of school science who have the opportunity to recreate their own knowledge of science differ in terms of thinking and talking styles.

In this manner, Leach and Scott (2002) clarified the term learning demand that is an evaluation of the differences and commonalities between the social languages of school science and the everyday social languages. Learning demand can be considered in clarifying the TDMs of the Level 2. In identifying learning demand, Leach and Scott (2002) specified the following three distinctive but interrelated aspects, conceptual tools, epistemological underpinnings, and ontological commitments.

Conceptual tools, learning demand and TDMs: For example, in terms of the conceptual tools of learning demand, students may suppose that forces have actions that either pull or push. However, there may be cases where a certain amount of force is not able to push or pull a heavier or fixed object. In this case, the learning demand is higher since there is a contradiction with students' prior reasoning pertaining to the concepts of force and motion. In a responsive manner, the teacher should display more dialogic TDMs (see also Table 3) such as using reflective 
questioning as a reflective toss (e.g., van Zee \& Minstrell, 1997b), giving students the opportunity to express ideas in order to discern their understanding (e.g., Crawford, 2000) or posing a question that stimulates student thinking instead of giving direct corrective feedback (e.g., Chin, 2006, 2007). However, when students try to conceptualise, for instance, the parts of human skeleton, the teacher may directly introduce the terms to students by means of more monologically-oriented TDMs such as direct lecturing. Thus, in the presence of varying learning demands on the parts of the students due to the conceptual tools they have held, displayed TDMs can be diversified in a purposeful manner. A teacher may operate monologic and dialogic TDMs in a combined manner while there are fluctuations in the learning demand.

Epistemological underpinnings, learning demand and TDMs: Many epistemological underpinnings of scientific work are absent in terms of the everyday social languages of learners (Chinn \& Brewer, 1993b; Duit \& Treagust, 1998). In this case of a teaching sequence, an epistemological learning demand may be weighted to require a wide range of epistemologicallyoriented (i.e., both more dialogic and more monologic) TDMs. Examples of these moves (see also Table 3) may be helping students to develop experimental strategies (e.g., Crawford, 2000), modelling and rehearsing aspects of processes of science (e.g., McMahon, 2012), supporting students in learning about scientific work (e.g., Crawford, 2000; McMahon, 2012), showing the attitudes and attributes of scientists by example (e.g., Crawford, 2000), stimulating multimodal thinking (e.g., Chin, 2007) or encouraging and prompting for justified and evidence-based reasoning (e.g., Simon et al., 2006). In conclusion, once the epistemological bases related to the phenomenon under negotiation are differentiated, on the parts of the students, diversifying learning demands can be occurred requiring a combined performing of the monologic and dialogic TDMs in a more instrumental manner.

Ontological commitments, learning demand and TDMs: There are concepts of science for which experts' process views are incommensurable with the students' materialistic views (e.g., Chi, 2008). In this case, learning demand is readjusted in an ontological sense, for instance, "Two candidates for these types of change are heat, which needs to change from a flowing fluid to energy in transit, and a gene, which needs to change from an inherited object to a biochemical process." (Fraser, Tobin \& McRobbie, 2012, p. 109). Thus, the learners' everyday social languages are matched with the materialistic view whereas social languages of scientist fit well with process views such as heat and gene concepts. When a learning demand is ontologically-oriented, the teacher may implement more dialogic and more monologic TDMs (see also Table 3), such as asking students to generate contexts for considering an issue (e.g., van Zee \& Minstrell, 1997a), pointing out flaws in the argument (e.g., Simon et al., 2006), sharing individual student ideas with the whole class (Bansal, 2018; Mortimer \& Scott, 2003; Scott, 1998; Tabach et al., 2019) or providing multiple opportunities for student judgments (van Zee \& Minstrell, 1997b) since students' material views need to be changed into scientists' process views as new ways of thinking and talking about natural phenomena. Similar to the relations between conceptuallyoriented and epistemologically-oriented learning demands of students and diversifying TDMs, there may be a close interaction between the ontologically-oriented learning demands of the students and operating particular TDMs in a harmonical and relevant manner.

To summarise, the Level 2 TDMs may be re-categorised using explore, work with, review discursive cycle to take learners' different learning demands into consideration. At this level, teachers must be able to undertake various TDMs in staging the scientific story, to render the scientific point of view conceivable to students in the social plane of classroom. There may be also a fundamental tension for teachers, in addition to staging the scientific story, as they should be able to overcome individual barriers to support personal meaning making and handing over responsibility to the students (Bruner, 1983, 1985, 1990), which, in Vygotskian terminology, is described as scaffolding student internalisation (Vygotsky, 1962, 1978, 1987) as the Level 3 TDMs depictured in this review. 


\section{Level 3 TDMs as scaffolding students' internalisation}

In the Vygotskian context, a teaching sequence incorporates three interrelated features; (i) staging the scientific story, (ii) supporting students' internalisations, (iii) handing over responsibility to the students (Leach \& Scott, 2002). The extracted TDMs were also re-examined pertaining scaffolding students' internalisations and Level 3 was established. First, each phases of student-led internalisation in the presence of the scaffolding TDMs is clarified within the context of this review. Then, scaffolding TDMs' status within other levels (Level 0, Level 1, and Level 2) will be located and interpreted.

Staging the scientific story: In staging a scientific story, the performance of a learning group is interactive and multimodal in nature (Kress et al., 1998). The staging process incorporates talk, various semiotic modes and diverse activities as the student experiments or the teacher demonstrations. The teacher's purpose in this staging is to make the scientific story intelligible and plausible to the whole class (Posner, Strike, Hewson, \& Gertzog, 1982). The related TDMs for staging the scientific story were well incorporated by the studies reviewed in this study.

Supporting students' internalisations: This aspect of TDMs pertains to scaffolding individual students to make personal sense of and become able to use a negotiated scientific story (e.g., Leach \& Scott, 2002). Vygotsky (1987) constructed the idea that teachers are ones of endorsing students' intellectual progressions in the Zone of Proximal Development (ZPD), which involves assisted and unassisted student actions. Scaffolding TDMs were well investigated (e.g., Griffin \& Cole, 1984; Maybin et al., 1992) but the findings demonstrated that the teacher cannot scaffold students' internalisation through, for instance, using a CD-ROM program to teach the molecular kinetic theory of gases (Leach \& Scott, 2002). The process of scaffolding student internalisation requires sensitive teacher interventions in the progress of a learner who is actively involved in some specific task, but who is not quite able to manage the task alone. The teacher provides "guidance and support which is increased or withdrawn in response to the developing competence of the learner" (Mercer, 1995, p. 74, 75). Scaffolding students' internalisation, therefore, incorporates a measured withdrawal of teacher assistance in the process of handing over responsibility to students in a gradual sense (Bruner, 1983; Scott, 1998).

Handing-over responsibility to students: The important point is that TDMs for supporting student internalisation must be dispersed throughout the teaching sequence. Thus, "It is not a case of making the scientific story available (e.g., Level 2 TDMs) and then helping the students to make sense of it." (Leach \& Scott, 2002, p. 123, original emphasize). To achieve authentic teacher scaffolding for students' meaning making, teachers should be able to attain continuous monitoring of student comprehension and behave in a responding manner to their understanding regardless of whether student-generated ideas are related to the intended social languages from a scientific point of view (Scott, 1997). In this monitoring, teachers can use planned interventions such as teacher questioning (e.g., Louca, Zacharia \& Tzialli, 2012; Oliveira, 2010), whole class negotiations (e.g., Bansal, 2018; Christodoulou \& Osborne, 2014; Tabach et al., 2019) and small group activities (e.g., Jadallah et al., 2011). In addition, engaging in a responsive array of discursive interactions, teachers can also put other TDMs into practice such as sharing important structured points in class (e.g., Mortimer \& Scott, 2003; Scott, 1998), challenging studentgenerated arguments (e.g., Christodoulou \& Osborne, 2014; Jadallah et al., 2011; Simon et al., 2006) and applying multimodal communication tools as learners' written practices (e.g., Chin, 2007; Oh, 2005, 2010). In the course of monitoring and responding, teachers provide opportunities for students to try out new ideas in the process of making the newly constructed knowledge, and therein, the TDMs are associated with the handing-over of the responsibility of learning to students in recognition of their increased competence in unassisted learning practices (Bruner, 1983; Scott, 1997).

\section{The absence of Level 3 TDMs}

It is clear from the reviewed studies that when scaffolding learning by pedagogical and instructional means (Scott, 1997), most of the time, teachers seemed to engage in discursive 
efforts on the interpsychological plane in the classroom. However, it is restricted since the internalisation of a concept is only fully completed in the presence of scaffolding TDMs dedicated to their students' personal meaning making processes within their intrapsychological planes (Bruner, 1983, 1990; Scott, 1997; Solomon, 1994; Vygotsky, 1987). The literature acknowledges that teachers can employ many TDMs to make scientific themes available to the whole classroom through marking the knowledge as significant and joint (e.g., Bansal, 2018; Edwards \& Mercer, 1987; Tabach et al., 2019), overlooking a student response (e.g., Mortimer \& Scott, 2003), paraphrasing a student's idea to select and modify the previously mentioned ideas (e.g., Leach \& Scott, 2002; Mortimer \& Scott, 2003; McMahon, 2012), invoking silence to permit student to articulate their ideas (e.g., van Zee \& Minstrell, 1997a, 1997b) or enacting a confirmatory exchange with a student who previously generated closer ideas concerning school science social languages (e.g., Bansal, 2018; Lemke, 1990). Most of the TDMs presented in this review are overly directed towards labelling the scientific themes available on the interpsychological plane of the classroom. They were not generally concerned with promoting personal meaning making on the intrapsychological plane and cannot be supposed as a plenitude of The TDMs for teachers to use in scaffolding students' internalisations. The TDMs that were concerned with scaffolding of learning within the intrapsychological plane have been, therefore, less visible to researchers and teachers. From the perspective of the researchers in the current review, the studies tended to analyse and report only the TDMs embedded in whole group discussions (Scott, 1998; Tabach et al., 2019). Therefore, there has been no further information concerning the types of the TDMs that are needed in the support of personal internalisation particularly in the small group discussions of students.

\section{DISCUSSION and CONCLUSIONS}

\section{An Extended Argument for the Gradual Qualities of the Reviewed TDMs}

The assertions presented below are based on the above-stated arguments derived from a critical review of the studies that had been researched into the TDMs. As mentioned, reviewed TDMs incorporated a hierarchy regarding teaching-learning phenomenon by means of discursive interactions and exchanges that are animated by the TDMs. As discussed, four levels (categories) for the reviewed TDMs were composed. These levels can be interpreted regarding the hierarchy among the reviewed TDMs in addition to the inclusivity, contributors of the classroom discourse (student-led voices vs. teacher-led voices) and pedagogical/discursive intentions of the discursive exchanges. In this sense, Table 4 was composed as a representation of the how the reviewed TDMs are associated with the other parts of teaching phenomenon.

In Table 4, the hierarchy (composed levels within the TDMs) displays the inclusivity among the reviewed TDMs. Inclusivity signifies that a lower categorisation of the TDMs (e.g., Level-0) did not consist of specific discursive moves that were contained by a higher categorisation of the TDMs (e.g., Level 2). In other words, a higher categorisation of the TDMs incorporated all detected TDMs within a lower categorisation in addition to distinctive TDMs that were not incorporated by the lower categorisation of the TDMs.

Table 4. A Systematic Representation of the Hierarchy

\begin{tabular}{ccccc}
\hline Hierarchy (TDMs) & Levels & $\begin{array}{c}\text { Inclusivity } \\
\text { (breadthness) }\end{array}$ & $\begin{array}{c}\text { Voices of the } \\
\text { discourse }\end{array}$ & $\begin{array}{c}\text { Discursive approach } \\
\text { (intention) }\end{array}$ \\
\hline Scaffolding & Level-3 & $\begin{array}{c}\text { Most } \\
\text { sophisticated }\end{array}$ & $\begin{array}{c}\text { Students and } \\
\text { teacher }\end{array}$ & $\begin{array}{c}\text { Learner-centred } \\
\text { teaching \& } \\
\text { individualised } \\
\text { learning }\end{array}$ \\
\hline Dialectical & Level-2 & $\begin{array}{c}\text { More } \\
\text { sophisticated }\end{array}$ & $\begin{array}{c}\text { Students and } \\
\text { teacher }\end{array}$ & $\begin{array}{c}\text { Learner-centred } \\
\text { teaching-learning }\end{array}$ \\
\hline Only dialogic TDMs & Level-1 & Equal & Only the students & $\begin{array}{c}\text { Individual-centred } \\
\text { learning }\end{array}$ \\
\hline $\begin{array}{c}\text { Only monologic } \\
\text { TDMs }\end{array}$ & Level-0 & Equal & Only the teacher & $\begin{array}{c}\text { Subject-centred } \\
\text { teaching }\end{array}$ \\
\hline
\end{tabular}


To explicate, in this review, a gradual sophistication was discovered among the reviewed TDMs. In the context of this review, more sophisticated denotes that a categorisation of the TDMs embodies a broader or more inclusive discursive actions and deliberations compare to other(s). In this review, this was where the notion of (inclusive) hierarchy came in. It was the hierarchy among the levels of the reviewed TDMs; demonstrating an expanding breadthness of diverse aspects of the discursive interactions and exchanges (see also Table 4). More complex levels (categories) of the TDMs were seen as including awareness of critical aspects of the discursive moves and presented in less sophisticated TDMs plus awareness of more additional discursive moves.

In this sense, there were three types of the inclusivity or breadthness among the levels of the reviewed TDMs (see also Table 4). These were equal, more sophisticated, and most sophisticated. As seen in Table 4, Level 0 (only monologic conception of teaching discourse) and Level 1 (only dialogic conception of teaching discourse) showed no overlap or inclusivity in terms of the complexity of the reviewed TDMs. This review therefore confirmed that monologic understandings (subject-centred teaching) do not possibly include of dialogic teaching (individual-centred learning), and dialogic understandings (including only student-led voices) do not include awareness of the possibility of monologic teaching (including only teacher-led voices). This allowed for a third conception, a dialectical enactment of the reviewed TDMs, which included awareness of both monologic and dialogic TDMs and was attributed as hierarchically inclusive of the other two levels of the TDMs.

In the case of this review, it was found out that a dialectical breadthness of teaching discourse (learner-centred teaching-learning) would include enactments of both monologic and dialogic TDMs. Thus, this gives teachers a dialectical understanding with the option of operating in either monologic or dialogic TDMs or both simultaneously within the same teaching sequence. When this was the case, there was a need to posit a dialectical category (level), as it would be inherently more sophisticated than (only) dialogic or (only) monologic categories.

This interpretation of the reviewed TDMs would make the monologic and the dialogic levels equal in sophistication regarding the discursive instrumentality of the TDMs. To illuminate, the monologic level is seemed not to include awareness of more aspects of the phenomenon (the stated TDMs) than the other as the dialogic level. These were the different aspects of the categorisation of the TDMs. Once two categories of the TDMs are equalled or not inclusive of each other; then one cannot be more sophisticated than the other. Only the dialectical categorisation of the TDMs could be regarded as more sophisticated than the other two.

Moreover, there was another hierarchy between dialectical and scaffolding category of the TDMS. To advocate, Level 3 TDMs incorporated both dialogic and monologic TDMs on the interpsychological plane. However, as the most sophisticated category of the TDMs, scaffolding, also were included the TDMs both on the interpsychological and intrapsychological planes in supporting and attaining internalisation of the phenomenon under negotiation by the mediation function of the rehearsed social languages during classroom discourse.

When dialogically-oriented and monologically-oriented TDMs are enacted in an isolated or exclusively mutual manner, they may not facilitate a true co-construction of meaning as showed by the reviewed studies. Appropriate combinations of the two parts of the TDMs may ensure a dialectical classroom context in which both everyday social languages of learners and social languages of school science can be featured in a pragmatist manner. However, a convenient harmony of the dialogic and monologic TDMs may not be sufficient in terms of scaffolding students' internalisations after negotiating the meaning by class members. Thus, teachers may be expected to perform more comprehensible TDMs or enlarge their repertoires regarding the enacted TDMs permitting both group-based and individual-based understandings of the science phenomenon. 


\section{Concluding Remarks}

Overall, a review of relevant studies pointed out several salient assertions about the TDMs. First, the TDMs are diverse in nature and numerous, particularly in the presence of teachers' intentional interactions with students. Furthermore, explicit connections were not revealed between more monologic TDMs and the knowledge transmission modes of teaching or between more dialogic TDMs and co-construction of knowledge. Thus, it can be acclaimed that more monologic TDMs might be suited to the knowledge-transmission modes of teaching; however, this may be only valid in the absence of more dialogic TDMs or in the case of more monologic TDMs being isolated from more dialogic ones. Accordingly, more dialogic TDMs may not be functional in terms of the authentic co-construction of knowledge in classrooms when the dialectical complementary interrelations of more monologic and more dialogic TDMs are ignored.

In addition, even though teachers can conduct more monologic and dialogic TDMs and simultaneously within the teaching cycles of explore, work with and review, this may not provide for an accurate completion of scaffolding learning for personal internalisations. For this review, it can be claimed that teachers may experience a fundamental discursive tension in terms of being able to fulfil the staging of the scientific story (Level 0; Level 1 and Level 2 TDMs), and throughout the process, ensuring learners' internalisations by means of scaffolding learning and handing over responsibility to students (Level 3 TDMs).

Another outcome of this review for researchers is that, if the co-construction of knowledge is an admitted combination of staging, scaffolding and handing over responsibility to the learners, a deeper understanding of TDMs particularly in accomplishing scaffolding should be attained in a similar way to clarifying TDMs for staging the scientific story. In a recent and influential work, Jadallah et al. (2011) sought to examine teachers' scaffolding moves during small group discussions. Asking children to sum up, asking for clarification, praising the use of evidence, prompting for evidence, prompting for positions or reasons and challenging were the detected TDMs within small group discussion while teachers performed one-to-one interactions. It may therefore be an impulsive study and should be considered by researchers in exploring TDMs in the sense of supporting learners' internalisations.

This review also produced worthwhile outcomes for science teachers. As mentioned above, a wide range of TDMs were defined encompassing diverse combinations of the monologic, dialogic, dialectical and scaffolding aspects of discursive interactions. Teachers as the external readers of research materials, therefore, may gain an awareness pertaining to their routine and essential discursive moves as defined in this review from many perspectives of Vygotskian teaching. They also may create an awareness regarding the crucial tension between the negotiation of meaning both on the interpsychological and on the intrapsychological planes in classrooms.

To achieve this premier pedagogical target, teachers should acquire knowledge about the relevant combinations of more monologic and more dialogic discursive moves to cope with the emergent and structural qualities of classrooms particularly in the presence of everyday social languages of learners. However, having knowledge of the TDMs defined and interpreted in this review is only a very basic beginning in the development of a pedagogical lens for them to actualize a true co-construction of knowledge through the co-operation of all the members. To extend this idea, Oliveira (2010) and Soysal $(2019 ; 2019)$ commented that many analytical complementary parts of the TDMs might be directly and explicitly taught to teachers in long-term professional development programs. In Oliveira's study, the teachers were introduced to teacherquestioning patterns and acquainted about the executive functioning of teacher-questioning as in the forms of the TDMs. This teacher-training program provided teachers with skills to advance their in-class questioning and, more importantly, they became pedagogically aware of the discursive power of teacher questioning. Thus, based on the outcomes of this review, teachers can design and implement specific professional development programs especially in order to extend the experiences of teachers regarding essential hierarchy among the different levels of the TDMs and their functions for fruitful classroom discourses on the interpsychological and intrapsychological planes. 


\section{REFERENCES}

Aguiar, O. G., Mortimer, E. F., \& Scott, P. (2010). Learning from and responding to students' questions: The authoritative and dialogic tension. Journal of Research in Science Teaching. 47(2), 174-193.

Aguiar, O.G., Mortimer, E. F., \& Scott, P. (2010). Learning from and responding to students' questions: The authoritative and dialogic tension. Journal of Research in Science Teaching, 47(2), 174-193.

Alexander, R.J. (2001). Culture and pedagogy: International comparisons in primary education. Oxford: Blackwell.

Alexander, R.J. (2006). Towards dialogic teaching: Rethinking classroom talk. New York, NY: Dialogos.

Bansal, G. (2018). Teacher discursive moves: conceptualising a schema of dialogic discourse in science classrooms. International Journal of Science Education, 40(15), 1891-1912.

Bakhtin, M. M (1934). Discourse in the novel. The dialogic imagination: Four essays. Trans. Michael Holquist and Caryl Emerson. Austin: University of Texas.

Bakhtin, M. M. (1981). The dialogic imagination: four essays by M. M. Bakhtin, Ed. Micheal Holquist, trans. Caryl Emerson and Micheal Holquist. University of Texas Press, Austin.

Bakhtin, M. M. (1986). Speech genres \& other late essays (Caryl Emerson and Michael Holquist, Ed. and Vern W. McGee, trans). Austin: University of Texas Press.

Brown, D., \& Clement, J. (1991). Classroom teaching experiments in mechanics. In Duit, R., Goldberg, F., \& Niedderer, H. (Editors), Research in physics learning: theoretical and empirical studies. Kiel, Germany: IPN.

Brown, K., \& Kennedy, H. (2011). Learning through conversation: exploring and extending teacher and children's involvement in classroom talk. Social Psychology International, 32(4), 377-396.

Bruner, J. (1983). Child's talk: Learning to use language. New York: Norton.

Bruner, J. (1985). Vygotsky: A historical and conceptual perspective. In Wertsch, J. (Ed.), Culture, communication and cognition: Vygotskian perspectives. Cambridge University Press, England.

Bruner, J. (1990). Acts of meaning. Cambridge, Mass.: Harvard University Press.

Buty, C., \& Mortimer, E.F. (2008). Dialogic/authoritative discourse and modeling in a high school teaching sequence on optics. International Journal of Science Education, 30(12), 1635-1660.

Candela, A. (2005). Students' participation as co-authoring of school institutional practices. Culture \& Psychology, 11, 321-337.

Carlsen, W.S. (1991). Questioning in classrooms: A sociolinguistic perspective. Educational Research, 61, 157-178.

Chi, M. T. H. (2008). Three types of conceptual change: Belief revision, mental model transformation, and categorical shift. In S. Vosniadou (Ed.), International handbook of research on conceptual change, (pp. 61-82). New York: Routledge.

Chin, C. (2006). Classroom interaction in science: Teacher questioning and feedback to students' responses. International Journal of Science Education, 28, 1315-1346.

Chin, C. (2007). Teacher questioning in science classrooms: Approaches that stimulate productive thinking. Journal of Research in Science Teaching, 44(6), 815-843.

Chinn, C. A., \& Brewer, W. F. (1993b). Factors that influence how people respond to anomalous data. Proceedings of the Fifteenth Annual Conference of the Cognitive Science Society, (pp. 318-323). Hillsdale, NJ: Erlbaum.

Christodoulou, A., \& Osborne, J. (2014). The science classroom as a site of epistemic talk: A case study of a teacher's attempts to teach science based on argument. Journal of Research in Science Teaching, 51(10), 1275-1300.

Crawford, B.A. (2000). Embracing the essence of inquiry: New roles for science teachers. Journal of Research in Science Teaching, 37, 916-937.

Duit, R., \& Treagust, D. (1998). Learning science: From behaviorism towards social constructivism and beyond. In B. J. Fraser \& K. G. Tobin (Eds.), International handbook of science education (pp. 3-25). Dordrecht, The Netherlands: Kluwer.

Edwards, D., \& Mercer, N. (1987). Common knowledge: The development of understanding in the classroom. London: Methuen.

Engle, R. A., \& Conant, F. R. (2002). Guiding principles for fostering productive disciplinary engagement: Explaining an emergent argument in a community of learners classroom. Cognition and Instruction, 20, 399-484.

Fraser, B. J., Tobin, K. G., \& McRobbie, C. J. (2012). International handbook of science education (Part one). Springer Dordrecht Heidelberg: London, New York.

Griffin, P., \& Cole, M. (1984). Current activity for the future: The Zo-Ped. In Rogoff, B., \& Wertsch, J. (eds.), Children's learning in the zone of the proximal development, (pp. 45-64). San Francisco: Jossey-Bass. 
Grinath A.S., \& Southerland, S.A. (2019). Applying the ambitious science teaching framework in undergraduate biology: Responsive talk moves that support explanatory rigor. Science Education, 103, 92122.

Jadallah, M., Anderson, R. C., Nguyen-Janiel, K., Miller, B. W., Kim, I. H., Kuo, L. J. (2011). Influence of a teacher's scaffolding moves during child-led small-group discussion. American Educational Research Journal, 48(1), 194-230.

Kawalkar, A., \& Vijapurkar, J. (2013). Scaffolding science talk: The role of teachers' questions in the inquiry classroom. International Journal of Science Education, 35(12), 2004-2027.

Kress, G., Ogborn, J., Jewitt, C., \& Tsatsarelis, C. (1998). Rhetorics of the science classroom: a multimodal approach. Mid-project consultative meeting texts. Institute of Education, University of London.

Leach, J., \& Scott, P. (1995). The demands of learning science concepts: issues of theory and practice. School Science Review, 76(277), 47-52.

Leach, J., \& Scott, P. (2000). The concept of learning demand as a tool for designing teaching sequences. Paper prepared at the meeting research-based teaching sequences, Université Paris VII, France, November 2000.

Leach, J. T., \& Scott, P. H. (2002). Designing and evaluating science teaching sequences: An approach drawing upon the concept of learning demand and a social constructivist perspective on learning. Studies in Science Education, 38, 115-142.

Lemke, J. L. (1990). Talking science: Language, learning and values. Norwoord, NJ: Ablex.

Lefstein, A. (2008). Changing classroom practice through the English national literacy strategy: A microinteractional perspective. American Educational Research Journal, 45, 701-737.

Louca, L. T., Zacharia, Z. C., \& Tzialli, D. (2012) Identification, interpretation-evaluation, response: An alternative framework for analyzing teacher discourse in science. International Journal of Science Education, 34(12), 1823-1856.

Mameli, C., \& Molinari, L. (2013). Interactive micro-processes in classroom discourse: turning points and emergent meanings. Research Papers in Education, 28(2), 196-211.

Maybin, J., Mercer, N., \& Stierer, B. (1992). Scaffolding learning in the classroom. In: K. Norman (Ed.), Thinking voices: The work of the National Oracy Project. Hodder and Stoughton, London.

McDermott, L. and Somers, M. (1991). Building a research base for curriculum development: an example from mechanics. In F. Goldberg and H. Niedderer (Editors): Research in physics learning: theoretical and empirical studies. Kiel, Germany: IPN.

McMahon, K. (2012). Case studies of interactive whole-class teaching in primary science: communicative approach and pedagogic purposes, International Journal of Science Education, 34(11), 1687-1708.

Mercer, N. (1995). The guided construction of knowledge. Clevedon: Multilingual Matters.

Mercer, N. (2000). Words and minds: how we use language to think together. London: Routledge.

Mercer, N. \& Dawes, L. (2014). The study of talk between teachers and students, from the 1970s until the 2010s. Oxford Review of Education, 40(4), 430-445.

Millar, R., Marechal, J-F., \& Tiberghien, A. (1999). 'Mapping' the domain-varieties of practical work. In Leach, J., \& Paulsen, A. C. (Editors): Practical work in science education: recent research studies. Dordrecht, NL: Kluwer.

Mortimer, E.F. (1998). Multivoicedness and univocality in classroom discourse: An example from theory of matter. International Journal of Science Education, 20, 67-82.

Mortimer, E. F., \& Scott, P. H. (2000). Analysing discourse in the science classroom. In J. Leach, R. Millar, \& J. Osborne (Eds). Improving science education: The contribution of research. Milton Keynes, UK: Open University Press.

Mortimer, E. F. \& Machado, A. H. (2000). Anomalies and conflicts in classroom discourse. Science Education, $84,429-444$.

Mortimer, E., \& Scott, P. (2003). Meaning making in secondary science classrooms. Maidenhead, England: Open University Press.

Molinari, L., C. Mameli, \& A., Gnisci. (2013). A sequential analysis of classroom discourse in Italian primary schools: The many faces of the IRF pattern. British Journal of Educational Psychology, 83, 414-430.

National Research Council. (1996). National science education standards. Washington, DC: National Academy Press.

Ogborn, J., Kress, G., Martins, I., \& McGillicuddy, K. (1996). Explaining science in the classroom. Buckingham: Open University Press.

Oh, P. S. (2005). Discursive roles of the teacher during class sessions for students presenting their science investigations. International Journal of Science Education, 27(15), 1825-1851. 
Oh, P. S. (2010). How can teachers help students formulate scientific hypotheses? Some strategies found in abductive inquiry activities of earth science. International Journal of Science Education, 32(4), 541560.

Oh, P.S., \& Campbell, T. (2013). Understanding of science classrooms in different countries through the analysis of discourse modes for building 'classroom science knowledge' (CSK). Journal of Korean Association for Science Education, 33(3), 597-625.

Oliveira, A. W., (2010). Improving teacher questioning in science inquiry discussions through professional development. Journal of Research in Science Teaching, 47(4), 422-453.

Pimentel, D. S. \& McNeill, K. L. (2013). Conducting talk in science classrooms: Investigating instructional moves and teachers' beliefs. Science Education, 97(3), 367-394.

Posner, G. J., Srtike, K. A., Hewson, P. W., \& Gertzog, W. A. (1982). Accommodation of a scientific conception: toward a theory of conceptual change. Science Education, 66(2), 211-227.

Rogoff, B. (1990). Apprenticeship in thinking: Cognitive development in social context. New York, NY: Oxford University Press.

Roth, W.-M. (1996). Teacher questioning in an open-inquiry learning environment: Interactions of context, content, and student responses. Journal of Research in Science Teaching, 33(7), 709-736.

Roychoudhury, A., \& Roth, W.-M. (1996). Interactions in an open-inquiry physics laboratory. International Journal of Science Education, 18(4), 423-445.

Scott, P. H. (1998). Teacher talk and meaning making in science classrooms: A Vygotskian analysis and review. Studies in Science Education, 32, 45-80.

Scott, P. H. (1997). Teaching and learning science concepts in classroom: talking a path from spontaneous to scientific knowledge. In Linguagem, cultura e cognicao reflexoes para o ensino de ciencias. Belo Horizonte, Brazil: Faculdade de Educacao da UFMG.

Scott, P. H., \& Mortimer, E. F. (2002). Discursive activity on the social plane of high school science classrooms: a tool for analysing and planning teaching interactions. Paper presented at the 2002 AERA Annual Meeting, New Orleans, USA, as part of the BERA invited symposium: Developments in sociocultural and activity theory analyses of learning in school.

Scott, P.H., Mortimer, E.F., \& Aguiar, O.G. (2006). The tension between authoritative and dialogic discourse: A fundamental characteristic of meaning making interactions in high school science lessons. Science Education, 90(7), 605-631.

Simon, S., Erduran, S., \& Osborne, J. (2006). Learning to teach argumentation: Research and development in the science classroom. International Journal of Science Education, 27, 137-162.

Sinclair, J. McH., \& Coulthard, R.M. (1975). Towards an analysis of discourse: The English used by teachers and students. London: Oxford University Press.

Solomon, J. (1994). The rise and fall of constructivism. Studies in Science Education, 23, 1-19.

Soysal, Y. (2018). Determining the Mechanics of Classroom Discourse in Vygotskian Sense: Teacher Discursive Moves Reconsidered. Research in Science Education, 1-25. DOI: 10.1007/s11165-0189747-2.

Soysal, Y. (2019). Fen Öğretiminde Öğretmenin Söylemsel Hamlelerinin Öğrenenlerin Akıl Yürütme Kalitelerine Etkisi: Söylem Analizi Yaklaşımı. Egitimde Nitel Araştırmalar Dergisi, 7(3), 1-38.

Sutton, C. (1992). Words, science and learning. Buckingham, UK: Open University Press.

Sutton, C. (1996). The scientific model as a form of speech. In Research in Science Education in Europe. G. Welford, J. Osborne, P. Scott (Eds.), pp. 143-152. London: Falmer Press.

Tabach, M., Hershkowitz, R., Azmon, S., \& Dreyfus, T. (2019). Following the Traces of Teachers' Talk-Moves in Their Students' Verbal and Written Responses. International Journal of Science and Mathematics Education, 1-20. DOI: 10.1007/s10763-019-09969-0.

Tytler, R., Aranda, G. (2015). Expert teachers' discursive moves in science class room interactive talk. International Journal of Science and Mathematics Education, 13(2), 425-446.

Wertsch, J.V. (1985). Vygotsky and the social formation of mind. Harvard University Press.

Wertsch, J.V. (1991). Voices of the mind: A sociocultural approach to mediated action. Cambridge, MA: Harvard University Press.

Wertsch, J. 1998. Mind as Action. New York NY: Oxford University Press

Westgate, D., \& Hughes, M. (1997). Identifying 'quality' in classroom talk: An enduring research task. Language and Education, 11(2), 125-139.

Wood, D. J., Bruner, J. S., \& Ross, G. (1976). The role of tutoring in problem solving. Journal of Psychology and Psychiatry, 17, 89-100.

van D. Booven, (2015). Revisiting the authoritative-dialogic tension in inquiry-based elementary science teacher questioning. International Journal of Science Education, 37(8), 1182-1201. 
van Zee, E.H., \& Minstrell, J. (1997a). Reflective discourse: Developing shared understandings in a physics classroom. International Journal of Science Education 19, 209-228.

van Zee, E.H., \& Minstrell, J. (1997b). Using questioning to guide student thinking. The Journal of the Learning Sciences, 6, 229-271.

Viennot, L., \& Rainson, S. (1999). Design and evaluation of a research based teaching sequence: the superposition of electric fields. International Journal of Science Education, 21(1), 1-16.

Vygotsky, L. S. (1962). Thought and language. Cambridge, MA: MIT Press.

Vygotsky, L. S. (1978). Mind in society. Cambridge, MA: Harvard University Press.

Vygotsky, L. S. (1981). The genesis of higher mental functions. In J. W. Wertsch (Ed.), The concept of activity in Soviet psychology (pp. 144-188). Armonk, NY: Sharpe.

Vygotsky, L. S. (1987). Thinking and speech (N. Minick, Trans.). In R. W. Rieber \& A. S. Carton (Eds.), The collected works of L. S. Vygotsky: Vol. 1. Problems of general psychology, (pp. 39- 285). New York: Plenum Press. (Original work published 1934).

Zohar, A (2006). The nature and development of teachers' metastrategic knowledge in the context of teaching higher order thinking. Journal of the Learning Sciences, 15(3), 331-377. 